TERESA BANASZAK*, RYSZARD MILLER*, ANITA ZIĘBA*

\title{
THERMAL-CATALYTIC OXIDATION OF WASTE GASES
}

Waste gases can be neutralized in the process of catalytic or thermal oxidation. The method of oxidation depends on the content of hydrocarbons in waste gas. Catalytic oxidation of waste gas is often preceded by its preheating to a given temperature. A thermal-catalytic oxidation of such a gas consists in its flame preheating to a working temperature of the catalyst bed. In this method, a flame is not only a source of heat, but also a source of radicals and some intermediate oxidation products which accelerate and promote oxidation of toxic components of waste gas.

In the paper, these is presented the effect of flame gas preheating in thermal-catalytic reactor on the oxidation efficiency of waste gas. A design of the surface streaming-diffusive burner and its oxidation efficiency are also described. Such a burner allows us to enlarge the surface of contact between the flame and waste gas and also increases the intensity of this gas mixing in the combustion zone.

\section{INTRODUCTION}

Due to a constant improvement of air quality standards an admissible level of air pollution caused by various branches of industry has to be lowered. This forces the industry to apply waste-free technologies or facilities and processes that reduce the amount of the waste gas emitted.

If organic substances are the main component of waste gas (which is characteristic of, e.g., chemical or petrochemical industry), they are most often neutralized by catalytic oxidation or thermal oxidation. The latter method is mostly used for neutralization of waste gas of medium or high concentration of hydrocarbons (from 0.1, i.e. the low limit of inflammability, to the concentrations insignificantly exceeding this limit). The main advantage of this process lies in its universality, which means that the waste gas can be of any composition. The main disadvantages of the method are as follows: the emission of secondary pollutants, e.g. $\mathrm{NO}_{x}, \mathrm{CO}$, polycyclic aromatic hydrocarbons (if we deal with imperfect combustion) and the necessity of applying medium and high temperatures (up to $1000 \mathrm{~K}$ ).

\footnotetext{
* Institute of Thermal Engineering and Fluid Mechanics, Wroclaw University of Technology, Wybrzeże Wyspiańskiego 27, 50-370 Wrocław, Poland.
} 
The catalytic oxidation is mostly used for oxidizing the waste gas containing very small or trace concentrations of hydrocarbons [1]-[3]. The temperature of 400-800 K is sufficient for total catalytic oxidation of most of the waste gas organic compounds. A high efficiency of the process at such a low temperature is a significant advantage of the method [4]-[6].

Unquestionable disadvantages of the catalytic oxidation of waste gases can be itemized as follows:

1. The catalyst often works selectively, thus not all of the toxic waste components are oxidized to the same degree and to the products harmless to environment.

2. The catalyst can be subjected to poisoning by toxins, e.g. sulphur, lead, phosphorus, arsenic and chlorine compounds. Their presence in the waste gas significantly decreases the catalyst activity because its active centers are blocked.

3 . The catalyst is sensitive to high temperature. Even a local overheating (a thermal stress) may cause the catalyst sintering and reduction of its active surface.

The catalytic oxidation of waste gas often has to be preceded by heating substrates to a determined temperature. The constructors of catalytic reactors rarely draw their attention to the way of the process operation [7], which manifests itself in a great variety of the reactors applied, especially the burners and heat exchangers whose design often allows the flame to be separated from the waste gas by diaphragms.

On the other hand, there is a no available data on the influence of the waste gas preheating on the efficiency of its oxidation. The investigations of the efficiency of catalytic incinerators consist almost exclusively in a detailed determination of the oxidation efficiency versus the temperature, load, catalyst properties and the waste gas composition [8]. The influence of electrical preheating on waste gas oxidation [9] and the influence of a thermal fragmentation of polymer compounds on their partial oxidation [10] are only partly known.

The authors of papers [9] and [10] only separate the preheating stage from the entire oxidation process, but they do not analyze the influence of gas heating on catalytic process.

Our previous research had proved the positive effect of flame preheating on oxidation of the waste gas [6]. The flame and the surrounding zone are not only the sources of heat needed for the waste gas preheating, but also the sources of radicals and active products of an intermediate oxidation (e.g. excited energetically) which make the process easier and faster.

The use of flame preheating in catalytic oxidation makes the development of a thermal-catalytic oxidation possible. The essence of the combined thermalcatalytic method consists in taking a full advantage of the preheating stage, which is possible due to a direct contact of the waste gas with the largest possible surface of a flame. Such gas heating was called a flame preheating. In the preheating 
process, the waste gas remains in a close contact with a highly active zone of the flame and its closest surroundings, which initiates the oxidation process. Preheated and partially oxidized waste gas enters the second stage of the process, which runs in the catalyst bed. In this stage, a further oxidation of organic components of waste gas proceeds.

This paper presents the results of a research into a thermal-catalytic neutralization of a waste gas comprising a very low concentration of toxic components whose oxidation does not produce the process temperature required.

\section{APPARATUS AND METHODS}

Investigation was started with the main aim of stating whether the waste gas preheating during catalytic oxidation affected the process efficiency. The research carried out in a laboratory installation dealt with:

1. The comparison of the efficiency of two methods, i.e. thermal-catalytic oxidation and catalytic oxidation, where a non-flame preheating was applied.

2. Checking whether the thermal process (proceeding within the flame) followed by catalytic process affects the latter during thermal-catalytic oxidation.

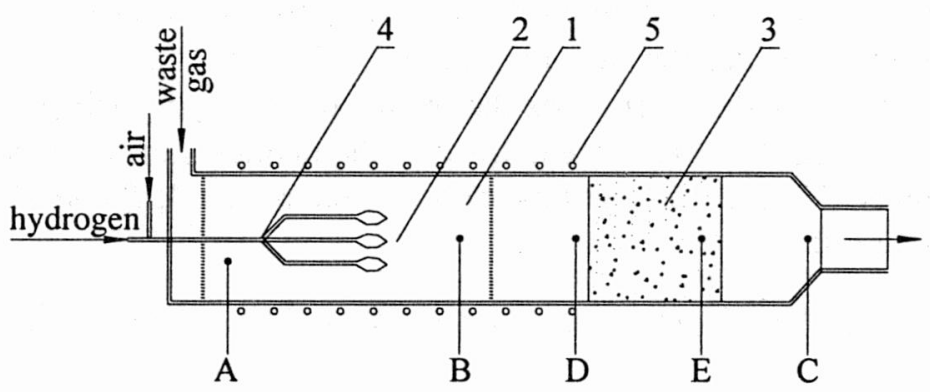

Fig. 1. Laboratory installation scheme: 1 - reactor, 2 - chamber of thermal combustion, 3 - chamber of catalytic oxidation, 4 - burner, 5 - electrical heater,

$A, B, C$-measuring points of waste gas component, $D, E$ - measuring points of temperature

Figure 1 shows a scheme of the laboratory installation for thermal-catalytic oxidation. It consists of a quartz flow reactor (1) whose length and diameter are 0.3 and $0.03 \mathrm{~m}$, respectively. A thermal combustion chamber (2) was equipped with a set of burners (4) used for waste gas preheating. The catalytic oxidation chamber was filled with a layer of the catalyst tested. In the non-flame preheating process, electrical heaters (5) were used instead of an open flame. The temperature in each chamber was measured using $\mathrm{NiCr}-\mathrm{NiAl}$ thermoelements. 
The analysis of the waste gas composition was carried out in a gaseous chromatograph HP $6890 \mathrm{GC}$. The waste gas was sampled in three measuring points: $A-$ at the reactor inlet, $B$ - ahead of the catalyst bed, $C$ - at the reactor outlet. The test was carried out in two measuring series. In the first series, the waste gas was flamelessly preheated by electrical heaters to working temperature of the catalyst bed, and then was subjected to catalytic oxidation. In the second series, the waste gas was preheated by open flames to working temperature of the catalyst bed, and then was subjected to thermal-catalytic oxidation. In this series, the burners were supplied with the same and exactly determined amount of fuel. An excessive rise in temperature was caused by electrical heaters.

The research was carried out under the following conditions:

- The temperature ranged from 370 to $750 \mathrm{~K}$.

- The catalyst load was $20000 \mathrm{l} / \mathrm{h}$.

- The concentration of toxic compounds (toluene, ethanol, ethyl acetate, $n$-heptane acetate, and acetone acetate) in the model waste gas was $1.0 \cdot 10^{-3} \mathrm{~kg} / \mathrm{m}^{3}$.

- Auxiliary fuel, i.e. hydrogen, was $27.8 \cdot 10^{-7} \mathrm{~m}^{3} / \mathrm{s}$.

The investigation was carried out using a commercial platinic catalyst PD-1 (Pt $=$ $0.1 \%)$, laboratory catalyst with a lowered content of platinum LK-9 $(\mathrm{Pt}=0.01 \%)$ and laboratory oxide catalyst with vanadium $(\mathrm{V})$ oxide $\left(\mathrm{V}_{2} \mathrm{O}_{5}=5 \%\right)$. All of the catalysts tested were deposited on an aluminium oxide $\left(\mathrm{Al}_{2} \mathrm{O}_{3}\right)$ carrier shaped in the form of porous grains with the diameter ranging from 3.5 to $5.0 \cdot 10^{-3} \mathrm{~m}$.

The efficiencies of the thermal oxidation $\eta_{T}$, the catalytic oxidation $\eta_{K}$ and the thermal-catalytic oxidation $\eta_{T K}$ were defined as the quotients of the concentrations of toxic compounds $C$ in the waste gas measured in the points $A, B$ and $C$ (figure 1) according to formulas:

$$
\eta_{T}=1-C_{B} / C_{A}, \quad \eta_{K}=1-C_{C} / C_{B}, \quad \eta_{T K}=1-C_{C} / C_{A} .
$$

Combustion of toxic components of waste gas is a multistage chemical reaction often associated with the formation of other toxic compounds. Thus, it is important to carry out the neutralization process in such a way as to limit the formation of toxic substances produced due to an incomplete oxidation.

The catalytic and thermal-catalytic processes were compared in terms of their abilities to restrict the formation of incomplete combustion products. The tests were carried out on a waste gas containing ethyl alcohol. Due to ethyl alcohol oxidation a large amount of acetic aldehyde is produced [11].

The oxidation efficiency of a waste gas containing ethyl alcohol was assessed on the basis of the percentage conversion of ethyl alcohol to acetate aldehyde $\left(y_{1}\right)$ and then to final products $\left(\mathrm{CO}_{2}, \mathrm{H}_{2} \mathrm{O}\right)\left(y_{2}\right)$ :

$$
y_{1}=C_{C\left(\mathrm{CH}_{3} \mathrm{CHO}\right)} / C_{A\left(\mathrm{C}_{2} \mathrm{H}_{5} \mathrm{OH}\right)}, \quad y_{2}=C_{C\left(\mathrm{CO}_{2}, \mathrm{H}_{2} \mathrm{O}\right)} / C_{A\left(\mathrm{C}_{2} \mathrm{H}_{5} \mathrm{OH}\right)} .
$$


The amount of ethyl alcohol, which is oxidized to final products, is estimated as:

$$
C_{C\left(\mathrm{CO}_{2}, \mathrm{H}_{2} \mathrm{O}\right)}=C_{A\left(\mathrm{C}_{2} \mathrm{H}_{5} \mathrm{OH}\right)}-\left(C_{\mathrm{C}_{\left(\mathrm{C}_{2} \mathrm{H}_{5} \mathrm{OH}\right)}}+C_{C\left(\mathrm{CH}_{3} \mathrm{CHO}\right)}\right) .
$$

The model waste gases were a mixture of air and one of the following compounds:

1. One toxic component ( $n$-heptane, toluene, acetone, ethyl acetate, ethyl alcohol) in the amount of $1.0 \cdot 10^{-3} \mathrm{~kg} / \mathrm{m}^{3}$.

2. Two toxic components in the appropriate mixtures M1-M6 (table 1).

Table 1

Components of mixtures

\begin{tabular}{cl}
\hline Mixtures & \multicolumn{1}{c}{ Components of mixtures } \\
\hline M1 & toluene $0.2 \cdot 10^{-3} \mathrm{~kg} / \mathrm{m}^{3}, n$-heptane $0.8 \cdot 10^{-3} \mathrm{~kg} / \mathrm{m}^{3}$ \\
M2 & toluene $0.5 \cdot 10^{-3} \mathrm{~kg} / \mathrm{m}^{3}, n$-heptane $0.5 \cdot 10^{-3} \mathrm{~kg} / \mathrm{m}^{3}$ \\
M3 & toluene $0.8 \cdot 10^{-3} \mathrm{~kg} / \mathrm{m}^{3}, n$-heptane $0.2 \cdot 10^{-3} \mathrm{~kg} / \mathrm{m}^{3}$ \\
M4 & toluene $0.5 \cdot 10^{-3} \mathrm{~kg} / \mathrm{m}^{3}$, acetone $1.0 \cdot 10^{-3} \mathrm{~kg} / \mathrm{m}^{3}$ \\
M5 & toluene $0.6 \cdot 10^{-3} \mathrm{~kg} / \mathrm{m}^{3}$, acetone $0.6 \cdot 10^{-3} \mathrm{~kg} / \mathrm{m}^{3}$ \\
M6 & toluene $1.0 \cdot 10^{-3} \mathrm{~kg} / \mathrm{m}^{3}$, acetone $0.5 \cdot 10^{-3} \mathrm{~kg} / \mathrm{m}^{3}$
\end{tabular}

\section{RESULTS}

The experiments proved that the way of waste gas preheating affected the oxidation efficiency. In all the cases tested, the efficiency of thermal-catalytic oxidation was higher than the efficiency of catalytic oxidation. This difference ranged from a few to a few dozens percent, depending on the temperature of the catalyst bed. The following configurations can exemplified the results obtained:

- Ethyl acetate - catalyst PD-1 (figure 2).

- Mixture of toluene and acetone - oxide catalyst $\left(5 \% \mathrm{~V}_{2} \mathrm{O}_{5}\right)$ (figure 3).

- Ethyl alcohol - catalyst PD-1 (figure 4).

The curve $\eta_{K}=f(T)$ (figure 2) shows that oxidation efficiency of ethyl acetate in catalytic installation is low. Initially, up to the temperature of $575 \mathrm{~K}$, the oxidation efficiency is constant, approaching 0.23 . A subsequent flame preheating of waste gas increases the ethyl acetate oxidation efficiency $\eta_{T K}$, on average, by ca. 0.15 in whole range of bed operation temperature. Thermal oxidation $\eta_{T}$ of waste gas in the preheating zone with a use of hydrogen as an auxiliary fuel is 0.2 in whole range of bed operation temperature.

The results presented in figure 3 also prove that the thermal-catalytic oxidation $\eta_{\mathrm{TK}}$ of both toluene and acetone surpasses the catalytic oxidation $\eta_{\mathrm{K}}$ in terms of efficiency. The application of flame preheating raises the toluene oxidation efficiency in 
whole temperature range by about 0.25 . During oxidation of acetone the initial difference in efficiency equal to 0.2 decreases as the temperature of catalytic bed rises.

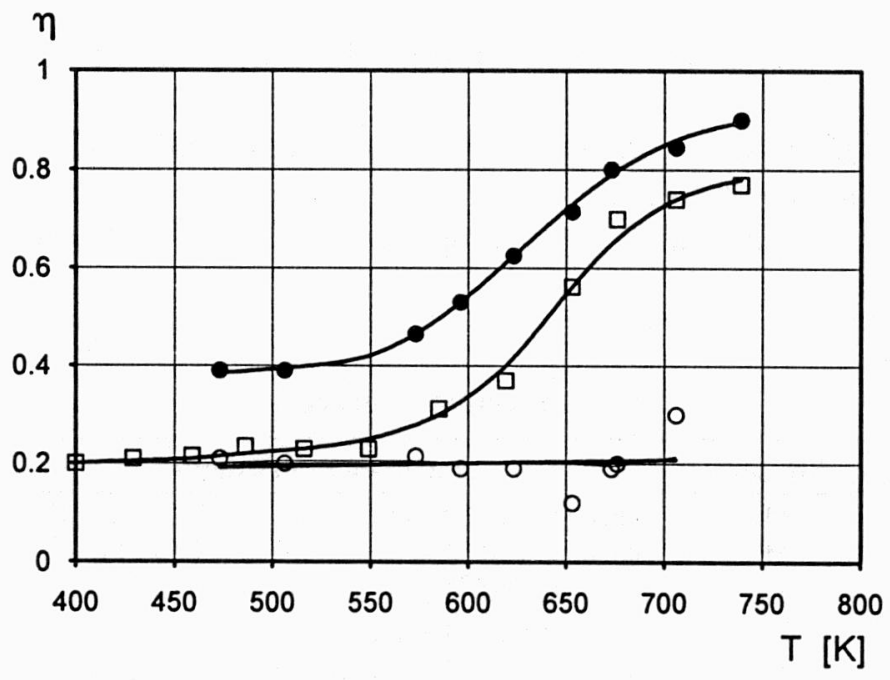

Fig. 2. Efficiency of thermal-catalytic $\left(\eta_{T K}\right)$, thermal $\left(\eta_{T}\right)$ and catalytic $\left(\eta_{K}\right)$ oxidation of ethyl acetate and acetate versus catalytic bed temperature. $\square-\eta_{K}$ flameless heating, $\circ-\eta_{T}$ flame heating, $\bullet-\eta_{T K}$ flame heating

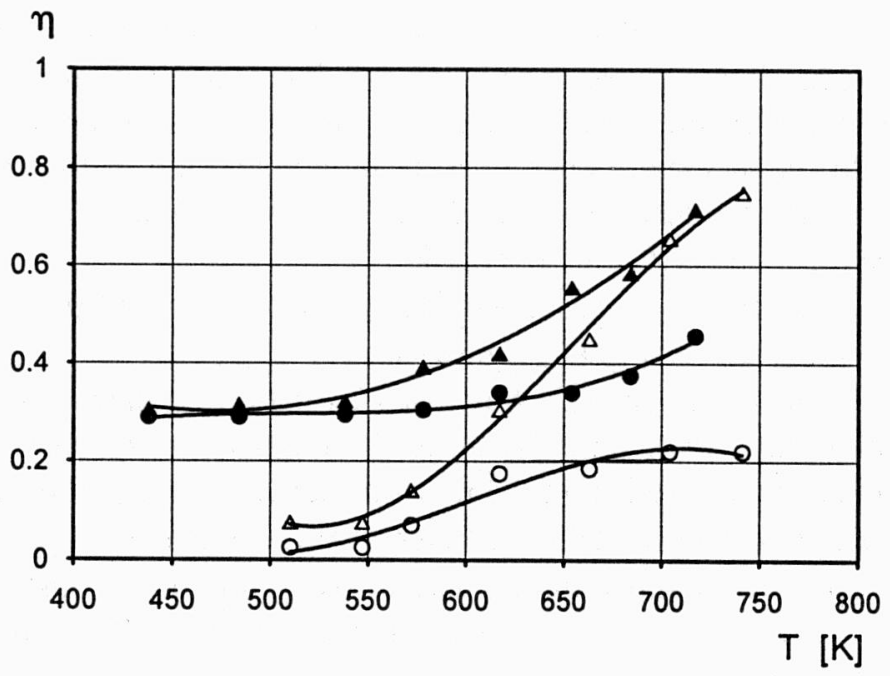

Fig. 3. Efficiency of thermal-catalytic $\left(\eta_{T K}\right)$, thermal $\left(\eta_{T}\right)$ and catalytic $\left(\eta_{K}\right)$ oxidation of toluene and ethyl acetate versus catalytic bed temperature: $०$ - toluene (flameless heating), $\Delta$ - acetone (flameless heating), $\bullet-$ toluene (flame heating), $\bullet-$ acetone (flame heating) 
Figure 4 shows the percentage conversion of ethyl alcohol to an indirect product of oxidation $\left(y_{1}\right)$ - aldehyde acetate, and to final products of oxidation $\left(y_{2}\right)$ versus the temperature of catalyst bed. Initially, at low temperature the concentration of aldehyde acetate increases, reaching its maximum at $475-500 \mathrm{~K}$; then, along with the rise in temperature, this concentration decreases and finally, at a temperature of $750 \mathrm{~K}$, it ceases. Due to flame preheating the concentration of aldehyde acetate $\left(y_{1}\right)$ considerably decreases at a temperature higher than $500 \mathrm{~K}$, but oxidation efficiency of ethanol to the final products $\left(y_{2}\right)$ increases. This increase is ca. 0.10 at low temperature $(500-600 \mathrm{~K})$ and up to 0.06 in high temperature of the catalyst bed operation.

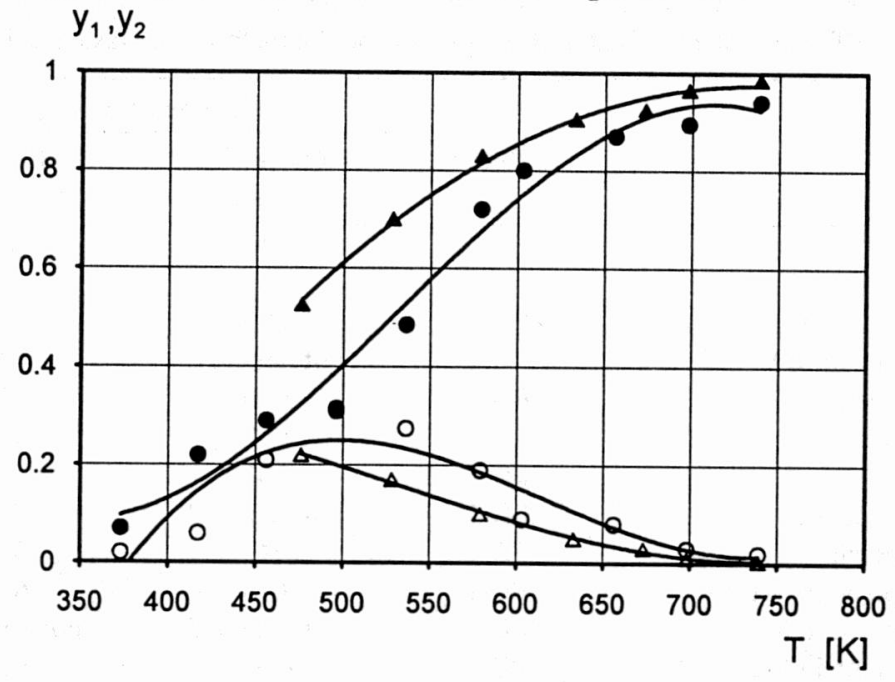

Fig. 4. Conversion ratio of ethyl alcohol to an incomplete product of oxidation, i.e. acetic aldehyde ( $\left.y_{1}\right)$, and final product of oxidation $\left(y_{2}\right)$ versus catalytic bed temperature: $\circ-y_{1}$, flameless heating, $\Delta-y_{1}$, flame heating, $\bullet-y_{2}$, flameless heating, $\bullet-y_{2}$, flame heating

Based on the results presented in tables 2 and 3 we can compare the efficiency of two different preheating methods applied to waste gas oxidation. As shown in table 2, at the same oxidation efficiency $\eta=0.9$ of waste gas being either flamelessly or flame preheated, the oxidation of the latter requires a considerably lower temperature. Using the chemically active flame and its post-flame zone allows us to decrease the temperature of catalyst bed operation by about $20-100$ degrees. This is followed by the decrease in fuel amount, and hence reduces the oxidation cost. The benefits of proper flame preheating in a catalytic oxidation installation are also shown in table 3 . The flame preheating enables oxidation of waste gas in the zone of thermal oxidation with the efficiency of 0.2 to 0.3 , which raises the efficiency of thermal-catalytic oxidation by 0.25 at the maximum.

In the mixtures of toluene- $n$-heptane and toluene-acetone, we observe usually the inhibitory effect of oxidizing of each waste gas component. This effect is independent of the 
way of waste gas heating. Both toluene and $n$-heptane in the mixture achieve the oxidation efficiency $\eta=0.9$ at lower temperature than in a model gas comprising one component only. The toluene being flamelessly preheated is the only exception (table 2). Similarly, the oxidation efficiency of the mixtures is lower compared with the oxidation efficiency of one component. However, there is exception to this general rule - a small amount of acetone catalyses the toluene oxidation in the flame surroundings (table 3 ).

Table 2

The temperature of catalytic bed at 0.9 efficiency of oxidation $T_{\eta K}=0.9, T_{\eta T K}=0.9[\mathrm{~K}]$ for different systems of catalyst-waste gas and the methods of waste gas heating

\begin{tabular}{lccc}
\hline \multirow{2}{*}{ Toxic component } & & \multicolumn{2}{c}{ Heating of waste gas } \\
\cline { 3 - 4 } & Catalyst & $\begin{array}{c}\text { Flameless } \\
T_{\eta K}=0.9\end{array}$ & $\begin{array}{c}\text { Flame } \\
T_{\eta T K}=0.9\end{array}$ \\
\hline Toluene & & 620 & 600 \\
Toluene & LK-9 & 685 & 545 \\
Toluene in M1 & PD-1 & 620 & 525 \\
Toluene in M2 & PD-1 & not obtained & 600 \\
Toluene in M3 & PD-1 & 620 & 575 \\
Ethanol & PD-1 & 650 & 600 \\
Ethanol & LK-9 & 600 & 535 \\
Ethyl acetate & PD-1 & not obtained & 730 \\
$n$-heptane & PD-1 & 645 & 645 \\
$n$-heptane in M1 & PD-1 & 675 & 650 \\
$n$-heptane in M2 & PD-1 & not obtained & not obtained \\
$n$-heptane in M3 & PD-1 & not obtained & 690
\end{tabular}

Table 3

Efficiency of waste gases' oxidation at a temperature of catalytic bed $T=740 \mathrm{~K}$

\begin{tabular}{lcccc}
\hline \multirow{2}{*}{$\begin{array}{c}\text { Toxic } \\
\text { component }\end{array}$} & Catalyst & \multicolumn{3}{c}{ Heating of waste gas } \\
\cline { 3 - 5 } & & $\eta_{K}$ & $\eta_{T K}$ & $\eta_{T}$ \\
\cline { 3 - 5 } & $\mathrm{V}_{2} \mathrm{O}_{5}$ & 0.34 & 0.40 & 0.20 \\
Toluene & $\mathrm{V}_{2} \mathrm{O}_{5}$ & 0.26 & 0.45 & 0.30 \\
Toluene in M4 & $\mathrm{V}_{2} \mathrm{O}_{5}$ & 0.22 & 0.45 & 0.20 \\
Toluene in M5 & $\mathrm{V}_{2} \mathrm{O}_{5}$ & 0.28 & 0.52 & 0.30 \\
Toluene in M6 & $\mathrm{V}_{2} \mathrm{O}_{5}$ & 0.76 & 0.80 & 0.35 \\
Acetone & $\mathrm{V}_{2} \mathrm{O}_{5}$ & 0.75 & 0.75 & 0.30 \\
Acetone in M4 & $\mathrm{V}_{2} \mathrm{O}_{5}$ & 0.70 & 0.70 & 0.15 \\
Acetone in M5 & $\mathrm{V}_{2} \mathrm{O}_{5}$ & 0.75 & 0.75 & 0.20 \\
Acetone in M6 & $\mathrm{PD}-1$ & 0.80 & 0.90 & 0.20 \\
Ethyl acetate & $\mathrm{LK}-9$ & 0.76 & 0.80 & 0.23 \\
Acetone & $\mathrm{LK}-9$ & 0.85 & 0.94 & 0.25 \\
Ethanol & & & &
\end{tabular}




\section{SURFACE BURNERS}

The rate and uniformity of the waste gas preheating depend on the intensity of its mixing with hot combustion gases [12]. Thus, when waste gas preheating is closely associated with an excessive, high caloric fuel burning, the method of this preheating is of a prime importance. The mixing process properly developed should create the optimum conditions for preheating and simultaneously for oxidizing the waste gas in the post-flame zone of the high caloric fuel flame. The waste gas molecules have to enter into a direct contact with the post-flame zone. They ought to be in the closest vicinity of the main flame zone where the concentration of radicals is high [12], [13]. During waste gas preheating in such a way the post-flame zone can be enormously beneficial. The flame also allows the catalyst to work under lower load of waste gas toxic components.

Surface burners provide a post-flame zone with high concentration of radicals. In such burners, the main stream of a high caloric fuel is divided into many small flames. The main construction elements of surface burners are stabilizers. Due to stabilizers a highly turbulent flow field appears, which guarantees good mixing and stable combustion. The burners are designed as modules. Such a construction enables assembling them into installations of a desired size and caloric effect. Because the surface burners operate within the field of a waste gas flow, in the recirculation zones, being rich in fuel and situated straight behind the stabilizers, hot combustion gases and waste gas mix quickly.

Fig. 5. Scheme of streaming-diffusive burner

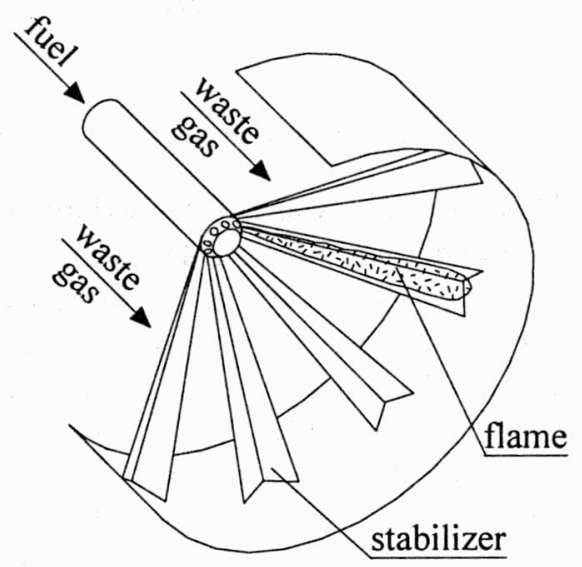

A combined streaming-diffusive burner is an example of a surface burner. It can be installed both in thermal and thermal-catalytic installations for waste gas oxidation [14]-[16]. This burner has an extended surface of contact between of a diffusive high caloric flame and the waste gas. Moreover, it guarantees low emission of nitric oxides (figure 5). It is shaped into a hemisphere whose surface is formed by the V-gutter 
stabilizers flowed round by the mixture of waste gas. The high caloric fuel is supplied by the central pipe and distributed among particular fuel jets situated in front of the stabilizers, where the fuel is burned diffusively. Due to such a construction a set of flames overlaying the whole cross-section of the waste gas stream is made up. This enlarges the surface of contact between the flame and the waste gas and also increases the intensity of waste gas mixing during oxidation.

The efficiency of oxidation of a toluene in a thermal-catalytic reactor, whose capacity is equal to $1000 \mathrm{~m}^{3} / \mathrm{h}$, and a use of a streaming-diffusive surface burner are shown in figure 6 [17].

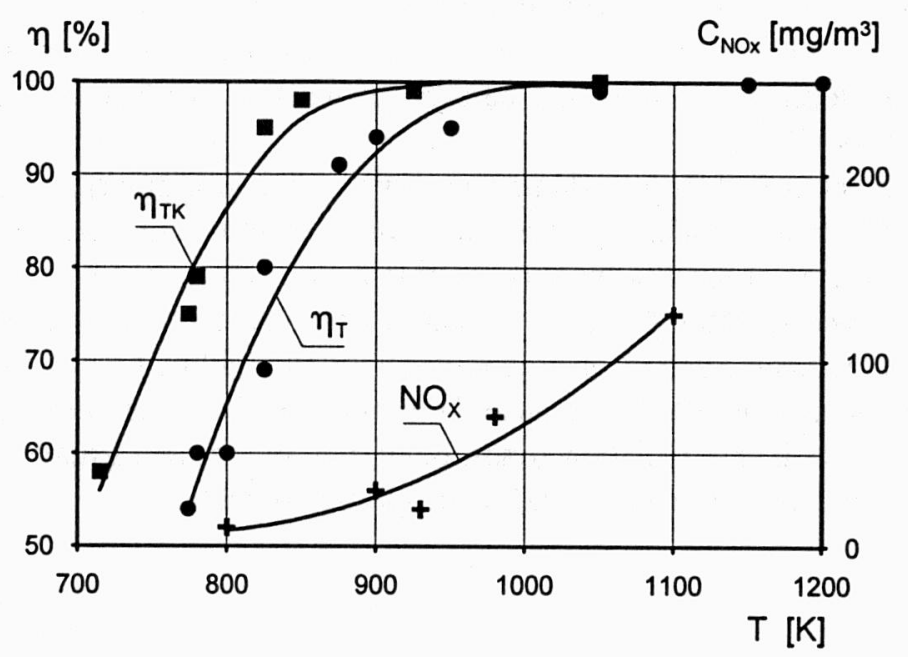

Fig. 6. Efficiency of toluene oxidation and $\mathrm{NO}_{x}$ generation in surface burner

This efficiency was determined by measuring a toluene concentration in front of and behind the burner and after the catalyst application. Additionally, the nitric oxides' concentration was measured at the reactor outlet. High efficiency of thermal oxidation of toluene in the preliminary phase considerably reduces initial concentration of toluene in the second phase (catalytic oxidation) and thus allows us to prolong the catalyst life and to achieve a high efficiency of the whole process of oxidation at substantially lower temperature. The concentration of nitric oxides reflects a proper control of burning process. Usage of methane as burners' fuel results in a very small emission of nitric oxides which is well within the accepted standards.

\section{CONCLUSIONS}

The research taken on different catalysts proves that the thermal-catalytic oxidation combined with a properly controlled process of the waste gas preheating is more 
efficient compared to the catalytic method without a flame preheating of the waste gas. Thus it is possible to decrease the amount of toxic compounds emitted to the atmosphere without increasing the consumption of an auxiliary fuel. The method also gives the possibility of reducing the catalysts bed working temperature in order to obtain the oxidation degree required. This is associated with the decrease in the amount of a high caloric fuel which is indispensable for preheating the waste gas to the temperature of catalyst bed.

The thermal-catalytic oxidation is an energy-saving and high-effective method of neutralizing the waste gas. The flame of a high caloric gas is a local source of high temperature and also of some highly reactive compounds - the radicals. In the nearest surroundings of the flame, the processes of oxidation initiation and oxidation take place, which results in the formation of final atoxic products of waste gas oxidation.

\section{REFERENCES}

[1] LAWTON T.J., Catalytic incineration in the printing industry, Platinum metals Review, Oct. 1989, Vol. 33, No. 4, pp. 178-180.

[2] MUSIALIK-PIOTROWSKA A., MENDYKA B., SYCZEWSKA K., Effect of sulphur and chlorine compounds on the activity of platinum catalysts, Environment Protection Engineering, 1987, Vol. 13, No. 3-4, pp. 89-101.

[3] EvSTROPOV A., BELANKIN I.A., i in., Katalitičeskij metod očistki gazovych vybrosov raspylitelnoi okrasočnoi kamery, Lakokrasocnye Materialy i ikh Primenene, 1988, No. 6, pp. 72-73.

[4] SADAKata T., ShIGENISA D., KUNII A., Development of a catalytic two-stage combustion systems, AICHE Journal, 1985, Vol. 31, No. 5, pp. 767-770.

[5] Ramanthan K., SPIVeY J.J., Catalytic oxidation of 1,1-dichloroethane, Combustion Science and Technology, 1989, Vol. 63, No. 4-6, pp. 247-255.

[6] ZiĘBA A., BANASZAK T., MiLleR R., Thermal-catalytic oxidation of waste gases, Applied Catalysis. General, 1995, 124, pp. 47-57.

[7] BySTROV G.A., GALNERIN V.M., TITOV B.P., Obezvreživanie $i$ utilizaciya otkhodov v proizvodstve plastmass, Leningradskoe Otdelenie, Chimija, 1982.

[8] Handbook. Control technologies for hazardous air pollutants, EPA/625/6 -86/014, Center for Environmental Research Information, Cincinnati, 1986.

[9] Tichenor B.A., PAlazzolo M.A., Destruction of voltaile organic compounds via catalytic incineration, Environmental Progress, 1987, Vol. 6, No. 3, pp. 172-176.

[10] Dessai F.N., Greene H.L., SubBanna P., Catalytic oxidation of decomposition products from spent ion-exchange resins, Industrial and Engineering Chemistry Research, 1987, Vol. 26, pp. 19651969.

[11] Iwasita T., Rasch B., Cattaneo E., Snifftirs study of ethanol oxidation on platinum, Electrochimica Acta, 1989, Vol. 34, No. 8, pp. 1073-1079.

[12] Miller R., Wptyw mieszania na utlenianie weglowodorów w strefie poptomiennej. I Sympozjum ograniczenia emisji zanieczyszczeń do atmosfery, POL-EMIS '92, Politechnika Wrocławska, Instytut Inżynierii Ochrony Środowiska, Szklarska Poręba, czerwiec 1992, pp. 87- 92.

[13] Khristich V.A., Milko E., ZARYTSKY A., NikodeM Z., ZembrZUSKI M., MilleR R., Some characteristic of mass transfer and burninig processes behind a V-gutter flame stabilizer, Archivum Combustionis, 1991, Vol. 11, No. 3-4, pp. 233-240. 
[14] Khristich V.A., Lyubchik G., Ivannikova L., Milko E., Miller R., Banaszak T., Palnik do termicznej $i$ katalitycznej neutralizacji gazów odpadowych, Konferencja: Termiczna Utylizacja Odpadów, Procesy, Maszyny i Urządzenia, Politechnika Śląska, Gliwice, maj 1991, pp. 15-18.

[15] Karcz H., Pec M., Miller R., Chmura J., Bas W., ChOrążyczewski J., Palnik gazów niskokalorycznych. Pat. PL 174450 B1, zgłoszono 29.07.1994, opublikowano 31.07.1998.

[16] MILlER R., Zastosowanie palników strumieniowo-stabilizacyjnych do neutralizacji składników toksycznych gazów odpadowych, Konferencja: Ochrona Powietrza Atmosferycznego Ekologia '91, Ustoń-Jaszowiec, 15-18. 01. 1991 r. zbiór opracowań autorskich, Fundacja Ochrony Środowiska, Rybnik.

[17] LyUbChiK G.N., Khristich V. A., Marczenko D.S., Miller R., BanaszaK T., Thermocatalytic incineration of waste gases - efficiency and $\mathrm{NO}_{x}$ emission, 14th International Symposium on Combustion Processes, Polish Academy of Sciences, 26-29 Sep., 1995, Częstochowa, Archivum Combustionis, 1996, Vol. 16, No. 1-2, pp. 97-111.

\section{TERMICZNO-KATALITYCZNE UTLENIANIE GAZW ODPADOWYCH}

Proces neutralizacji gazów odpadowych, w zależności od zawartości w nich węglowodorów, przeprowadza się metodą katalitycznego lub termicznego dopalania. Proces katalitycznego dopalania wymaga często wstępnego podgrzewania gazu odpadowego do określonej temperatury. Płomieniowe podgrzewanie gazu odpadowego w katalitycznym dopalaczu stanowi istotę termiczno-katalitycznej metody utleniania gazów odpadowych. W metodzie tej płomień wykorzystano nie tylko jako źródło ciepła, ale także jako źródło rodników i aktywnych pośrednich produktów utleniania ułatwiających i przyspieszających procesy unieszkodliwiania toksycznych składników gazu odpadowego.

Przestawiono wpływ realizacji płomieniowego podgrzewania gazu odpadowego w dopalaczu termiczno-katalitycznym na skuteczność procesu utleniania. Opisano także konstrukcję palnika powierzchniowego typu strumieniowo-dyfuzyjnego i wyniki badań efektywności jego działania. Konstrukcja tego palnika zapewnia dużą powierzchnię kontaktu płomienia z przepływającym gazem odpadowym oraz zwiększa intensywność mieszania gazu odpadowego w strefie spalania.

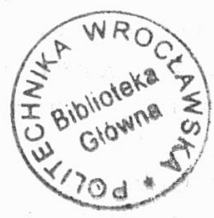

